\title{
Estimating the economic costs of skin cancer in New South Wales, Australia
}

\author{
Christopher M. Doran ${ }^{1 *}$, Rod Ling ${ }^{1}$, Joshua Byrnes², Melanie Crane ${ }^{3,4}$, Andrew Searles ${ }^{1}$, Donna Perez ${ }^{3}$ \\ and Anthony Shakeshaft ${ }^{5}$
}

\begin{abstract}
Background: Skin cancer is one of the most common cancers in the world. The increased incidence of skin cancer, combined with limited health care resources and tight budgetary conditions, has increased the importance of understanding the economic impact of skin cancer. This research estimates the economic cost of skin cancer in the Australian state of New South Wales.
\end{abstract}

Method: An incidence based approach is used to estimate lifetime costs of skin cancer. Both direct and indirect costs are considered - direct costs include resources associated with the management of skin cancer and indirect costs refer to productivity costs associated with morbidity and premature mortality. Diagnosis of skin cancer was determined according to ICD-10 codes using principal diagnosis. Linked administrative data and regression modelling are used to calculate costs; presented as Australian dollars for the year 2010. The human capital approach is used to value present and future productivity losses.

Results: The lifetime cost of the 150,000 incident cases of skin cancer diagnosed in NSW in 2010 is estimated at $\$ 536$ million ( $\$ 44,796$ per melanoma and $\$ 2459$ per non-melanoma). Direct costs accounted for $72 \%$ of costs $(\$ 10,230$ per melanoma and $\$ 2336$ per non-melanoma) and indirect costs accounted for $28 \%$ of costs $(\$ 34,567$ per melanoma and $\$ 123$ per non-melanoma). Direct costs are, on average, higher for females than males with indirect costs, on average, higher for males than females.

Conclusion: This research provides new evidence on the economic cost of skin cancer and provides policy makers with information of the potential monetary savings that may arise from efforts to reduce the incidence of skin cancer.

Keywords: Economic, Cost, Skin cancer, Epidemiology, New South Wales, Australia

\section{Background}

Skin cancer is one of the most common cancers in the world [1-4]. The majority of skin cancers develop from exposure to ultraviolet radiation (UVR), particularly from sun exposure. The highest incidence rates of skin cancer worldwide are in Australia and New Zealand, where two out of every three people are likely to be diagnosed in their lifetime [5].

Basal cell carcinoma (BCC) is the most common form of skin cancer followed by squamous cell carcinoma (SCC) $[1,2]$. Together, BCC and SCC make up the majority of

\footnotetext{
* Correspondence: chris.doran@hmri.com.au

${ }^{1}$ Hunter Medical Research Institute, University of Newcastle, Locked Bag 1000, New Lambton, NSW 2305, Australia

Full list of author information is available at the end of the article
}

non-melanoma skin cancers (NMSC). Malignant melanoma accounts for less than five percent of skin cancer cases, yet it represents the vast majority of skin cancer deaths in Australia [6]. The incidence of skin cancer is increasing in Australia, and the incidence rate is greater than breast, prostate, lung and colon cancers combined. In terms of prevalence, more people have been diagnosed with skin cancer than all other cancers combined over the past three decades [7].

The management of skin cancer generally involves diagnosis, treatment and follow-up. Melanoma, SCC and BCC are typically detected opportunistically during specific skin examinations by skin cancer specialists or dermatologists, or during general health checks by a general practitioner. In Australia, the standard treatment for 
primary melanoma is wide local excision of the skin and subcutaneous tissues around the melanoma. The aim is complete surgical excision of all in situ and invasive melanoma components, confirmed by comprehensive histological examination [8]. Surgery is the prime treatment for NMSC: more than $70 \%$ of the $\mathrm{BCC}$ lesions recorded in the 2002 National survey were surgically excised [9]. For BCCs not surgically excised, cryotherapy was more commonly used for upper and lower limb lesions than facial lesions, and $10 \%$ of BCCs were treated with curettage and diathermy. Anecdotal evidence suggests that nonsurgical treatment has increased since 2002 for superficial BCC with imiquimod in particular. The majority of SCC lesions, regardless of body site, were treated by surgical excision $[9,10]$. Confirmation of complete removal of lesions is an essential part of management [10].

The post-treatment follow-up regimen is relatively intensive in Australia with clinical guidelines recommending post melanoma treatment follow-up visits every sixmonths for five years for patients with stage I disease, three-monthly or four-monthly for five years for patients with stage II or III disease, and yearly thereafter for all patients [8]. NMSC recommendations for follow-up have yet to be established for the detection of further primary tumours, however, some suggestions have been made that six-monthly follow-up for two years may assist in early detection of new primary tumours or of metastatic disease [10].

The incidence of skin cancer increases with age $[11,12]$. With most western countries experiencing a demographic transition towards an older cohort, including Australia, the incidence and prevalence of skin cancer is rising, along with the consequential economic impact, even though incidence in younger age groups (i.e., less than 55 years) is stabilising [12-14].

The economic impact of skin cancer can be considered as a combination of direct and indirect costs. Direct costs include the management of skin cancer from diagnosis, treatment to follow-up, and refer to the utilisation of health care resources such as hospital, medical and allied health care services. Indirect costs reflect the lost productivity resulting from an individual's inability to work (morbidity costs such as sick leave and early retirement) and premature mortality (defined as death before the age of 65 years, the upper limit of the working age in Australia).

The increased incidence and prevalence of skin cancers, combined with the current fiscal environment of limited health care resources and tight budgetary conditions, has increased the importance of understanding the economic impact of skin cancer. From a policy viewpoint, it is important to understand the resource requirements of the current skin cancer burden and the efficiency of competing strategies that are most likely to lower the incidence of skin cancer and, therefore, reduce its burden. Although several international studies have examined the direct cost of skin cancer treatment [15-26], and two have examined indirect costs [27, 28]; our review of the literature found only four studies that had combined both direct and indirect costs in the same analysis [29-32]. Morris et al. [31] estimated the cost of skin cancer in England in 2002 at $£ 240$ million, equivalent to $£ 4249$ per case (AUD\$12,567 in 2010 prices). Tinghog et al. [29] estimated the cost of melanoma and NMSC in Sweden in 2005 at $€ 116$ million, equivalent to $€ 3019$ per case (AUD\$5366 in 2010 prices). Eriksson and Tinghog [32] updated the 2005 Swedish estimate and reported a combined cost of melanoma and NMSC at $€ 136$ million. The authors did not report incidence rates or average cost per case, but noted that costs had risen by $14 \%$ after adjusting for inflation since 1995 [32]. O’Dea estimated the cost of skin cancer in New Zealand in 2007 at \$NZ123.10 million, equivalent to $\$ N Z 1,785$ per case (AUD\$1650 in 2010 prices) [30]. The general trend in these country specific studies is higher direct costs for NMSC (because of their relatively high prevalence) and higher indirect costs for melanoma (because of its relatively greater severity of illness in those of working age). Although the proportion of costs attributable to indirect costs in all three studies to date appears comparable at around $54 \%$, total costs appear to vary widely partly due to methodological differences.

New South Wales (NSW) is Australia's most populated state with an estimated population of 7.29 million (34.5\% of the population of Australia). One of the key objectives of the skin cancer prevention strategy for NSW (20122015 ) is to increase and utilise evidence to inform future planning and development of skin cancer prevention strategies with a priority on: increasing the adoption of UVR protection behaviours; increasing shade provision; and improving polices to increase protection from UVR across a range of settings and life stages [33]. Although an understanding of the magnitude of the economic burden of skin cancer in NSW is important given its high incidence, there is currently a clear lack of such evidence. The objective of this study is to estimate the economic cost (both direct and indirect) of skin cancer in NSW. A lifetime approach is adopted, which estimates costs over the management of skin cancer through diagnosis, treatment and follow-up.

\section{Methods}

\section{Ethics}

Ethics clearance was obtained from the New South Wales Ministry of Health (2012/09/417).

\section{Economic approach}

Economic costs may be estimated using either the prevalence or incidence-based approach to costing. A 
prevalence-based approach provides estimates of costs for the total population for one year, or costs accumulated over a longer time horizon [34]. An incidencebased approach follows a disease cohort for the duration of the disease and estimates discounted costs [34], it is the most commonly used method as it allows policy makers to understand the potential impact of reducing the incidence of a disease by adopting cost-effective strategies. This analysis uses the incidence based approach to estimate lifetime economic costs. This lifetime perspective reflects the recommended clinical management of skin cancer in Australia [8, 10], managing melanoma and NMSC for five and two years respectively, post diagnosis. Total economic costs in 2010 are derived by multiplying the number of incident cases in 2010 by estimates of the average lifetime direct and indirect costs.

\section{Epidemiological data}

In Australia, melanoma is notifiable to cancer registries. To estimate the incidence of melanoma by age and gender, data were obtained from the NSW Central Cancer Registry (CCR) which at the time of writing was available up to 2008 [35]. These data were combined with Australian Bureau of Statistics (ABS) estimates of the resident NSW population in 2010 [36].

Unlike melanoma and other invasive cancers, NMSC is not notifiable by law to cancer registries in Australia, despite being the most commonly diagnosed cancer. Consequently, rates of NMSC have been estimated from population surveys $[5,9,37,38]$. The most recent survey was conducted by the National Cancer Control Initiative (NCCI) in 2002 [9]. To estimate the incidence of NMSC by age and gender, data from the NCCI survey were combined with ABS estimates of the resident NSW population in 2010 [36].

\section{Calculating direct costs of skin cancer Data sources}

A range of linked data sources (Table 1) were utilised to determine direct costs: the 45 and Up study (45\&Up) [39]; NSW CCR [35]; NSW admitted patient data collection (APDC) [40]; ABS mortality [6]; Pharmaceutical Benefit Schedule (PBS) [41]; Medicare Benefit Schedule (MBS) [42]; and, the NSW Registry of Births, Deaths and Marriages (RBDM) [43].

\section{Diagnosis of skin cancer}

Diagnosis of melanoma (both in-situ and invasive) was determined by the principal diagnoses codes in the Australian modified International Statistical Classification of Diseases and related health problems, 10th revision (ICD-10-AM), specifically codes C43 (malignant melanoma of skin) and D03 (melanoma in situ) [44]. Diagnosis of NMSC was identified using codes C44 (malignant neoplasm of skin) and D04 (carcinoma in situ of skin). Diagnosis was also derived from MBS and PBS utilisation and self-report data from the $45 \& U p$ study.

\section{Analysis criteria}

Costs were calculated for, and compared across, three diagnostic groups: melanoma; NMSC; and, neither melanoma or NMSC. Participants self-reported having either melanoma or NMSC in the 45\&Up survey by their responses to the following two questions: "Has a doctor EVER told you that you have melanoma?" "Has a doctor EVER told you that you have skin cancer (not melanoma)?" Self-reported responses were validated by linked records in the CCR, APDC and MBS. Participants without CCR, APDC or MBS records were classified as diagnosis uncertain if their evidence of diagnosis - for either skin cancer - was only self-identification in the 45\&Up survey or only relevant MBS records. This group was omitted from analysis due to the ambiguity of their status. The group 'neither melanoma or NMSC' had no data relevant to melanoma or NMSC diagnosis and is used as the control group in the regression analysis.

\section{Direct costs}

Cost groupings were derived from the following sources (data periods appear in brackets):

1. Primary care medical costs: MBS (04/08/2003 to 31/ 12/2011)

2. Pharmaceutical costs: PBS (01/06/2004 to 31/12/ 2011)

3. Hospital costs: APDC (01/07/2000 to 31/12/2011)

Variations in data coverage reflect the nature of linking multiple patient-level data sources. To ensure consistency, data from these files were analysed only for their overlap period, 01/06/2004 to 31/12/2011. MBS, PBS and APDC cost estimates were converted to 2010 prices using appropriate price inflators [45].

Estimation of lifetime direct costs used longitudinal methods to estimate average costs (MBS, PBS and APDC), for each diagnosis group, for each calendar year since diagnosis - for 5 years post diagnosis for melanoma and 2 years post diagnosis for NMSC. A cost per annum from year of diagnosis reflects that any cost difference between those with and without a diagnosis is likely to be most pronounced in the first years of diagnosis. Regression analysis is used to estimate the effect on the cost associated with a diagnosis of either melanoma or NMSC, compared to the control group, i.e., those without a diagnosis. The dependent variable is the average annual cost for the year as identified as the year from diagnosis. The covariates included in this model are 
Table 1 Summary of available administrative data

\begin{tabular}{|c|c|c|c|c|}
\hline Data source & Abbreviation & Overview of data collected & Period of data collection & $\begin{array}{l}\text { Number of } \\
\text { possible records }\end{array}$ \\
\hline 45 and Up survey & $45 \&$ Up & $\begin{array}{l}\text { The 45\&Up survey is of individuals aged } 45 \text { and over in } \\
\text { NSW - the survey includes information on health, lifestyle } \\
\text { and other socio-economic factors. }\end{array}$ & $2005-2009$ & $\begin{array}{l}267,119 \text { records } \\
\text { (267,119 } \\
\text { persons) }\end{array}$ \\
\hline $\begin{array}{l}\text { NSW Central Cancer } \\
\text { Registry }\end{array}$ & CCR & $\begin{array}{l}\text { The CCR includes records for all reported cancer cases } \\
\text { from NSW Central Cancer Registry. The CCR records } \\
\text { include a range of demographic data items (e.g. date of birth, } \\
\text { residential address), staging information, year of diagnosis, } \\
\text { plus diagnostic information (e.g. reason for death, Morphology } \\
\text { code, Topography Code etc.). The CCR cohort comprises } \\
\text { individuals registered on NSW CCR and diagnosed with } \\
\text { skin cancer (melanoma, melanoma in situ). }\end{array}$ & $\begin{array}{l}\text { January } 1994- \\
\text { December } 2008\end{array}$ & $\begin{array}{l}63,342 \text { records } \\
(60,247 \text { persons })\end{array}$ \\
\hline $\begin{array}{l}\text { NSW Admitted } \\
\text { Patient Data } \\
\text { Collection }\end{array}$ & APDC & $\begin{array}{l}\text { The APDC includes all hospital separations of skin cancer } \\
\text { (melanoma, melanoma in situ, non-melanoma) and/or a } \\
\text { precursor of skin cancer (sunburn, actinic keratosis or } \\
\text { melanocytic naevi) in NSW during the period July 2000-Dec } 2011 \\
\text { from all NSW public and private hospitals and day procedure } \\
\text { centres. APDC records include a range of demographic data } \\
\text { items, administrative items (e.g. admission and separation dates) } \\
\text { and diagnostic information (e.g. reason for admission, significant } \\
\text { co-morbidities and complications and procedures performed } \\
\text { during the admission). }\end{array}$ & $\begin{array}{l}\text { July } 2000 \text { - December } \\
2011\end{array}$ & $\begin{array}{l}406,997 \text { records } \\
(256,924 \\
\text { persons) }\end{array}$ \\
\hline $\begin{array}{l}\text { Australian Bureau of } \\
\text { Statistics (ABS) } \\
\text { mortality }\end{array}$ & $\begin{array}{l}\text { ABS } \\
\text { Mortality }\end{array}$ & $\begin{array}{l}\text { The ABS cohort includes all cases where skin cancer is } \\
\text { recorded as the primary or contributing cause of death. } \\
\text { Cause of death is coded according to the International } \\
\text { Statistical Classification of Diseases and Related Problems } \\
\text { (ICD-10-AM). }\end{array}$ & $\begin{array}{l}\text { January } 2000- \\
\text { December } 2007\end{array}$ & $\begin{array}{l}5735 \text { records } \\
\text { (5728 persons) }\end{array}$ \\
\hline $\begin{array}{l}\text { Pharmaceutical } \\
\text { Benefit Schedule }\end{array}$ & PBS & $\begin{array}{l}\text { The PBS is administered by Medicare Australia and includes } \\
\text { all processing claims and payment benefits for pharmaceutical } \\
\text { medications for most medical conditions. This source contains } \\
\text { cost and utilisation data by drug for each individual. }\end{array}$ & $2004-2011$ & $\begin{array}{l}35,322,2457 \\
\text { records }\end{array}$ \\
\hline $\begin{array}{l}\text { Medicare Benefit } \\
\text { Schedule }\end{array}$ & MBS & $\begin{array}{l}\text { The MBS is a listing of medical and hospital services that are } \\
\text { subsidised by the Australian government. The MBS includes } \\
\text { primary care practitioner and specialist consultations and exclude } \\
\text { ambulance and allied health services. This source contains costs } \\
\text { (including patient out of pocket cost) and utilisation data by } \\
\text { service/procedure. }\end{array}$ & 2003-2011 & $\begin{array}{l}46,012,797 \\
\text { records }\end{array}$ \\
\hline $\begin{array}{l}\text { NSW Registry of } \\
\text { Births, Deaths and } \\
\text { Marriages }\end{array}$ & $\begin{array}{l}\text { RBDM } \\
\text { deaths }\end{array}$ & $\begin{array}{l}\text { The Registrar of the NSW Registry of Births, Deaths and Marriages } \\
\text { (RBDM) is a registry all births and deaths in NSW }\end{array}$ & $\begin{array}{l}\text { RBDM records linked to } \\
45 \& \text { Up, CCR, APDC and } \\
\text { ABS }\end{array}$ & $\begin{array}{l}66,786 \text { records } \\
(62,688 \text { persons })\end{array}$ \\
\hline
\end{tabular}

listed in Table 2 and include the years from diagnosis as an explanatory variable.

The analysis can be represented by the following equation:

$$
\begin{aligned}
\mathrm{ALC}= & \left.\mathrm{NPV}\left[\mathrm{CM}_{\mathrm{i}}\right] \times \mathrm{IM}\right]+\mathrm{NPV}\left[\mathrm{CNMSC}_{\mathrm{i}}\right] \\
& \times \text { INMSC }
\end{aligned}
$$

Where:

- $\quad \mathrm{ALC}=$ average lifetime cost of skin cancers diagnosed in 2010;

○ NPV = net present value

o $\mathrm{CM}_{i}=$ average annual cost per case of melanoma relative to year of diagnosis $i$; $\circ \mathrm{CNMSC}_{i}=$ average annual cost per case of NMSC relative to year of diagnosis $i$;
O IM = incidence of melanoma in 2010;

○ INMSC = incidence of NMSC in 2010.

From each data source (MBS, PBS, APDC) cost data was obtained for each calendar year of the collection period (2004-2011). The data sets were merged on person number and year. The dataset had one record for each participant for each calendar year of the collection period. Records contained fields for calendar year MBS, PBS, APDC costs and, for participants with skin cancer, years since year of diagnosis. Costs are inclusive of patient and government contributions. Participants who died during the collection period only had records for the calendar years in which they were alive. Mortality information was sourced from ABS mortality [6] and the NSW Registry of Births, Deaths and Marriages (RBDM) [43]. 
Table 2 Variables used in costing analysis

\begin{tabular}{|c|c|c|c|c|}
\hline Variables & Sources & Question/Nariable & $\begin{array}{l}\text { Data } \\
\text { Format }\end{array}$ & Analysis summary \\
\hline \multirow[t]{3}{*}{ Medical Charges } & APDC & Average costs per AR-DRGs (from government 'Costs of Care' reports & $\begin{array}{l}\text { Continuous } \\
\text { (\$) }\end{array}$ & $\begin{array}{l}\text { Averages and totals across } \\
\text { diagnosis groups and periods }\end{array}$ \\
\hline & MBS & Charges & $\begin{array}{l}\text { Continuous } \\
(\$)\end{array}$ & $\begin{array}{l}\text { Averages and totals across } \\
\text { diagnosis groups and periods }\end{array}$ \\
\hline & PBS & Gross Price & $\begin{array}{l}\text { Continuous } \\
\text { (\$) }\end{array}$ & $\begin{array}{l}\text { Averages and totals across } \\
\text { diagnosis groups and periods }\end{array}$ \\
\hline \multirow{4}{*}{$\begin{array}{l}\text { Diagnoses } \\
\text { Melanoma }\end{array}$} & CCR & Inclusion in the CCR & & Inclusion \\
\hline & $45 \& \cup p$ & Question: 'Has a doctor ever told you that you have melanoma'? & Yes/No & Proportions \\
\hline & MBS & Relevant MBS Charges & $\begin{array}{l}\text { Continuous } \\
\text { (\$) }\end{array}$ & $\begin{array}{l}\text { Averages and totals across } \\
\text { diagnosis groups and periods }\end{array}$ \\
\hline & APDC & Relevant Primary Diagnoses items & $\begin{array}{l}\text { Continuous } \\
\text { (\$) }\end{array}$ & $\begin{array}{l}\text { Averages and totals across } \\
\text { diagnosis groups and periods }\end{array}$ \\
\hline \multirow[t]{3}{*}{ Diagnosis NMSC } & $45 \& \cup p$ & $\begin{array}{l}\text { Question: 'Has a doctor ever told you that you have skin cancer } \\
\text { (NMSC)'? }\end{array}$ & Yes/No & Proportions \\
\hline & MBS & Relevant MBS Charges & $\begin{array}{l}\text { Continuous } \\
(\$)\end{array}$ & $\begin{array}{l}\text { Averages and totals across } \\
\text { diagnosis groups and periods }\end{array}$ \\
\hline & APDC & Relevant Primary Diagnoses items & $\begin{array}{l}\text { Continuous } \\
\text { (\$) }\end{array}$ & $\begin{array}{l}\text { Averages and totals across } \\
\text { diagnosis groups and periods }\end{array}$ \\
\hline \multirow{3}{*}{$\begin{array}{l}\text { Diagnosis Calendar } \\
\text { Year (melanoma) }\end{array}$} & CCR & Year of Diagnosis' variable & Year & \\
\hline & APDC & Date of Separation & Year & \\
\hline & $45 \& \cup p$ & $\begin{array}{l}\text { Question: 'At what age were you told you had melanoma?' (Allows } \\
\text { calculation of year with variable 'Year of Birth') }\end{array}$ & Continuous & $\begin{array}{l}\text { Averages and totals across } \\
\text { diagnosis groups and periods }\end{array}$ \\
\hline \multirow[t]{2}{*}{$\begin{array}{l}\text { Diagnosis Calendar } \\
\text { Year (NMSC) }\end{array}$} & $45 \& \cup p$ & $\begin{array}{l}\text { Question: 'At what age were you told you had skin cancer (NMSC)' } \\
\text { (Allows calculation of year with variable 'Year of Birth') }\end{array}$ & Continuous & $\begin{array}{l}\text { Averages and totals across } \\
\text { diagnosis groups and periods }\end{array}$ \\
\hline & APDC & Date of Separation & Year & \\
\hline \multirow[t]{2}{*}{ Demographics } & $45 \& \cup p$ & Year of birth & Year & Year \\
\hline & & Gender & $\begin{array}{l}\text { Female/ } \\
\text { Male }\end{array}$ & Proportions \\
\hline Year of Death & RBDM & Year of death variable & Year & Year \\
\hline
\end{tabular}

APDC NSW Admitted patient data collection; CCR NSW Central Cancer Registry; MBS Medicate Benefit Schedule; PBS Pharmaceutical Benefit Scheme; RBDM NSW Registry of Births, Deaths and Marriages; 45\&UP The 45 and Up study

Regression modelling for average lifetime direct costs used General Estimating Equations (GEE) analysis. Given a priori evidence of skewed cost data (i.e., large number of zero or small cost observations with a small number of observations with very large costs), GEEs were run with a gamma family and log link. Standard diagnostic tests were conducted (e.g. correlations between independent variables and comparisons of residuals and predicted values). Robust variance estimators were included to ensure more robust estimates of standard errors. Margins (estimates) were derived for average treatment costs for each year from diagnosis by each diagnosis status (melanoma, NMSC) and compared to average annual direct costs for people with no skin cancers. These incremental results were then multiplied by skin cancer incidence figures to derive lifetime direct costs for NSW in 2010.
All regressions were conducted with STATA 12 software. Regression results are available from authors upon request.

\section{Calculating indirect costs of skin cancer}

Indirect costs quantified in this analysis include morbidity and premature mortality for those of working age.

\section{Morbidity estimates}

The Australian Burden of Disease study provide information on total years lived with a disease and the loss of health (referred to as a disability weight - DW) associated with that disease [46]. Disability weights are based on a scale ranging from 0 to 1 where 0 represents perfect health and 1 represents death [46]. For skin cancer, a range of DWs are used to reflect health states in relation to sequelae. Across the entire disease spectrum, the 
average DW is 0.19 and 0.06 for melanoma and NMSC, respectively. An estimate of the average health years of life lost due to skin cancer are used as a proxy for morbidity costs in this analysis and are derived by dividing total years lived with skin cancer with the relevant DW.

The human capital approach is used in this analysis to value the loss of productive life. The approach equates the value of a human life to the discounted market value of the output produced by an individual over an expected lifetime. In other words it uses forgone income to estimate forgone productivity [34, 47]. The value of a healthy year of life is equivalent to the average annual earnings in NSW for 2010 - $\$ 61,105$ for males and $\$ 42,238$ for females [48]. A further adjustment is made to this value to reflect the likelihood of being employed - $82 \%$ in males and $68 \%$ in females [49].

\section{Premature mortality}

Premature mortality costs are derived by valuing potential years of life lost (PYLL) due to skin cancer before the age of 65 . The most comprehensive source of skin cancer mortality data in NSW is provided by the ABS [6]. Dividing ABS data on PYLL with number of deaths provides an estimate of average years of life lost per death.

ABS data does not, however, report age of death so an alternate means was required to estimate average years of life lost due to skin cancer before the age of 65 . The CCR provides individual level data on age at melanoma diagnosis and age at death [35]. For melanoma, CCR data suggest that 38 and $35 \%$ of total years of life were lost in those dying before the age of 65 years, for males and females respectively. In the absence of similar CCR data for NMSC, this proportion is applied to ABS data on PYLL and deaths to estimate the average years of productive life lost per incident case of skin cancer.

As above for morbidity, average annual earnings, adjusted for employment, is used as a proxy for the value of a productive year. All future costs are converted to present value using a $3 \%$ discount rate.

\section{Results}

\section{Epidemiology}

Table 3 provides an overview of skin cancer epidemiology in NSW. In 2010, there were an estimated 3797 new cases of melanoma (2295 male and 1502 female) and 148,610 new cases of NMSC (86,812 male and 61,798 female). Equivalent age-standardised incidence rates are, for melanoma, 65 and 42 per 100,000 males and females, respectively; and, for NMSC, 2449 and 1716 per 100,000 males and females, respectively. For melanoma, the average years of healthy life lost are 3.66 for males (equivalent to 254 days) and 1.77 years for females (equivalent to 123 days). For NMSC, the average years of healthy life lost are 0.05 years for males (equivalent to 16 days) and 0.02 years for females (equivalent to 6 days).

In 2010, 359 men and 155 women lost their lives to melanoma corresponding to an age-standardised death rate of 9.8 and 3.6 per 100,000 for males and females, respectively. NMSC claimed the lives of 104 men and 41 females, corresponding to an age-standardised death rate of 2.9 and 0.8 per 100,000 for males and females, respectively. For melanoma, PYLL per death are 9.34 years for males and 10.14 years for females. For NMSC, PYLL per death are 5.44 years for males and 2.53 for females. For those dying of melanoma before the age of 65 years

Table 3 Epidemiology of skin cancer in New South Wales, 2010

\begin{tabular}{|c|c|c|c|c|}
\hline & \multicolumn{2}{|c|}{ Melanoma } & \multicolumn{2}{|l|}{ NMSC } \\
\hline & Males & Females & Males & Females \\
\hline \multicolumn{5}{|l|}{ Incidence } \\
\hline Incident cases & 2295 & 1502 & $86,812^{a}$ & $61,798^{\mathrm{a}}$ \\
\hline Incidence rate per 100,000 & 65 & 42 & 2449 & 1716 \\
\hline \multicolumn{5}{|l|}{ Morbidity } \\
\hline Total years lived with disease & 19,332 & 7089 & 9933 & 2533 \\
\hline Average healthy years of life lost due to disease & 3.66 & 1.77 & 0.05 & 0.02 \\
\hline \multicolumn{5}{|l|}{ Mortality } \\
\hline Deaths (2010) & 359 & 155 & 104 & 41 \\
\hline Total years of life lost & 3353 & 1571 & 566 & 104 \\
\hline Average years of life lost & 9.34 & 10.14 & 5.44 & 2.53 \\
\hline \multicolumn{5}{|l|}{ Mortality before the age of 65 years } \\
\hline Average years of productive life lost & 4.52 & 5.14 & 2.07 & 0.88 \\
\hline
\end{tabular}

${ }^{a}$ NMSC is estimated from a $2002 \mathrm{NCCl}$ report - the incident rate is assumed steady for 2010 and has not risen 
(i.e., $38 \%$ males and $35 \%$ of females), the average years of productive life lost are 4.52 years for males and 5.14 years for females. For those dying of NMSC before the age of 65 years (i.e., $38 \%$ males and $35 \%$ of females), the average years of productive life lost are 2.07 years for males and 0.88 years for females.

\section{Economic cost of skin cancer}

The lifetime economic cost of skin cancer cases in NSW in 2010 is estimated at AUD\$536 million or AUD\$3514 per incident case (Table 4). Each incident melanoma case costs an average AUD $\$ 44,796$ compared with AUD\$2459 per NMSC case. NMSC costs account for $68 \%$ (AUD\$365 million) of total lifetime economic costs. Direct lifetime costs are estimated at AUD\$386 million (AUD\$2533 per case), with NMSC representing $90 \%$ of total direct costs - AUD\$347 million (AUD\$2336 per case) and melanoma $10 \%$ of total direct costs - AUD\$39 million (AUD\$10,230 per case). Indirect lifetime costs are estimated at AUD $\$ 150$ million (AUD\$981 per case) with melanoma representing $88 \%$ of total indirect costs - AUD $\$ 131$ million (AUD $\$ 34,567$ per case) and NMSC $12 \%$ of total indirect costs - AUD\$18 million (AUD\$123 per case). Direct lifetime costs are, on average, higher for females than males with indirect costs, on average, higher for males than females.

\section{Discussion}

In conducting this study a range of data sources and methods were used. As such, a number of potential limitations and strengths of the analysis need to be considered.

\section{Limitations}

First, while the CCR data informed the incidence of melanoma in NSW, partial data sources were relied on to develop an understanding of the incidence of NMSC. These data sources are dated and may not reflect recent changes in incidence of NMSC. Second, our analysis did not consider the cost of skin cancer by stage of diagnosis, type of treatment, treatment provider or socio-economic status. Evidence suggests that there are variations in costs across these categories [15-18]. In our study, although CCR provided information on staging of disease at time of diagnosis, no other data set had comparable data. Third, the base year for the analysis is 2010. This year is appropriate given data availability but it is acknowledged that skin cancer management may have changed over recent years. Fourth, a limitation of productivity estimates is a

Table 4 Incident cases, direct cost, indirect cost and total cost of skin cancer in NSW, 2010

\begin{tabular}{|c|c|c|c|}
\hline & Melanoma & NMSC & Total \\
\hline \multicolumn{4}{|l|}{ Incident cases } \\
\hline Female & 1502 & $61,798^{\mathrm{b}}$ & 63,300 \\
\hline Males & 2295 & $86,812^{b}$ & 89,106 \\
\hline Total & 3797 & $148,610^{b}$ & 152,407 \\
\hline \multicolumn{4}{|l|}{ Direct costs } \\
\hline Females & $\$ 16,349,530$ & $\$ 230,717,528$ & $\$ 247,067,059$ \\
\hline Cost per female incident case & $\$ 10,882$ & $\$ 3733$ & $\$ 3903$ \\
\hline Males & $\$ 22,494,516$ & $\$ 116,426,574$ & $\$ 138,921,090$ \\
\hline Cost per male incident case & $\$ 9803$ & $\$ 1341$ & $\$ 1559$ \\
\hline Total & $\$ 38,844,046$ & $\$ 347,144,102$ & $\$ 385,988,148$ \\
\hline Cost per incident case & $\$ 10,230$ & $\$ 2336$ & $\$ 2533$ \\
\hline \multicolumn{4}{|l|}{ Indirect costs } \\
\hline Females & $\$ 34,928,193$ & $\$ 2,259,156$ & $\$ 37,187,349$ \\
\hline Cost per female incident case & $\$ 23,249$ & $\$ 37$ & $\$ 587$ \\
\hline Males & $\$ 96,325,255$ & $\$ 16,016,487$ & $\$ 112,341,742$ \\
\hline Cost per male incident case & $\$ 41,977$ & $\$ 184$ & $\$ 1261$ \\
\hline Total & $\$ 131,253,448$ & $\$ 18,275,643$ & $\$ 149,529,091$ \\
\hline Cost per incident case & $\$ 34,567$ & $\$ 123$ & $\$ 981$ \\
\hline Total costs & $\$ 170,097,494$ & $\$ 365,419,746$ & $\$ 535,517,240$ \\
\hline Cost per incident case & $\$ 44,796$ & $\$ 2459$ & $\$ 3514$ \\
\hline
\end{tabular}

${ }^{a}$ Average cost may not equate to total cost divided with cases due to rounding

${ }^{\mathrm{b}} \mathrm{NMSC}$ is estimated from a $2002 \mathrm{NCCl}$ report - the incident rate is assumed steady for 2010 and has not risen 
Table 5 Summary of skin cancer costing studies, Australia, England, Sweden and New Zealand

\begin{tabular}{|c|c|c|c|c|c|c|c|c|}
\hline Study & Country & $\begin{array}{l}\text { Year and } \\
\text { currency }\end{array}$ & Cases & $\begin{array}{l}\text { Direct cost } \\
\text { (million) }\end{array}$ & $\begin{array}{l}\text { Indirect costs } \\
\text { (million) }\end{array}$ & $\begin{array}{l}\text { Total cost } \\
\text { (million) }\end{array}$ & $\begin{array}{l}\text { Cost per } \\
\text { case }\end{array}$ & $\begin{array}{l}\text { Equivalent AUD } \\
\$ 2010\end{array}$ \\
\hline Morris & England & 2002 UK pounds & & & & & & \\
\hline Melanoma & & & 6062 & $£ 24$ & $£ 114$ & $£ 138$ & $£ 22,835$ & $\$ 67,537$ \\
\hline NMSC & & & 50,394 & $£ 97$ & $£ 5$ & $£ 101$ & $£ 2014$ & $\$ 5955$ \\
\hline $\begin{array}{l}\text { Skin } \\
\text { cancer }\end{array}$ & & & 56,456 & $£ 121$ & $£ 119$ & $£ 240$ & $£ 4249$ & $\$ 12,567$ \\
\hline Tinghog & Sweden & 2005 Euros & & & & & & \\
\hline Melanoma & & & 2122 & $€ 22$ & $€ 58$ & $€ 80$ & $€ 37,545$ & $\$ 66,738$ \\
\hline NMSC & & & 36,262 & $€ 31$ & $€ 5$ & $€ 36$ & $€ 998$ & $\$ 1775$ \\
\hline $\begin{array}{l}\text { Skin } \\
\text { cancer }\end{array}$ & & & 38,384 & $€ 53$ & $€ 63$ & $€ 116$ & $€ 3019$ & $\$ 5366$ \\
\hline O'Dea & $\begin{array}{l}\text { New } \\
\text { Zealand }\end{array}$ & $\begin{array}{l}\text { 2007/8 NZ } \\
\text { dollar }\end{array}$ & & & & & & \\
\hline Melanoma & & & 1982 & $\$ 6$ & $\$ 59$ & $\$ 65$ & $\$ 32,795$ & $\$ 30,326$ \\
\hline NMSC & & & 67,000 & $\$ 51$ & $\$ 7$ & $\$ 58$ & $\$ 867$ & $\$ 802$ \\
\hline $\begin{array}{l}\text { Skin } \\
\text { cancer }\end{array}$ & & & 68,982 & $\$ 57$ & $\$ 66$ & $\$ 123$ & $\$ 1785$ & $\$ 1650$ \\
\hline AlHW & Australia & 1993-94 AUD & & & & & & \\
\hline Melanoma & & & 6954 & $\$ 66$ & & $\$ 66$ & $\$ 9433$ & $\$ 14,805$ \\
\hline NMSC & & & 243,691 & $\$ 232$ & & $\$ 232$ & $\$ 953$ & $\$ 1496$ \\
\hline $\begin{array}{l}\text { Skin } \\
\text { cancer }\end{array}$ & & & 250,645 & $\$ 298$ & & $\$ 298$ & $\$ 1189$ & $\$ 1865$ \\
\hline AlHW & Australia & 2000-01 AUD & & & & & & \\
\hline Melanoma & & & 8885 & $\$ 30$ & & $\$ 30$ & $\$ 3376$ & $\$ 4561$ \\
\hline NMSC & & & 364,140 & $\$ 264$ & & $\$ 264$ & $\$ 725$ & $\$ 979$ \\
\hline $\begin{array}{l}\text { Skin } \\
\text { cancer }\end{array}$ & & & 373,025 & $\$ 294$ & & $\$ 294$ & $\$ 788$ & $\$ 1065$ \\
\hline
\end{tabular}

Source: Morris et al. (2009) [31], Tinghog et al. (2008) [29], O’Dea (2009) [30]

lack of complete Industry data. A recent study conducted by Safe Work Australia on exposure to direct sunlight and the provision of sun exposure controls in Australian workplaces, provides evidence that certain workers have a higher likelihood of being exposed to direct sunlight [50]. Further, the report suggests that the provision of sun protection (i.e. sunscreen, protective clothing, hats, sunglasses and being able to reorganise work outside peak UVR hours) was affected by worker employment and demographic characteristics [50]. The lack of data precludes a more robust assessment of Industry-related costs due to skin cancer in this analysis. Fifth, the analysis did not value the contribution made by carers. A report by Access Economics for Carer's Australia examined and valued the amount of informal care being provided in Australia [51]. The report suggests that in 2010, over 1 in 8 Australians (2.87 million people) were estimated to be providing informal care with each carer providing up to $9 \mathrm{~h}$ per week in informal care. In the absence of any data related to the number of carers' for skin cancer patients, carer costs were excluded.

\section{Strengths}

A strength of the analysis is the use of linked epidemiological data. Data linkage transforms routinely collected administrative data into a powerful resource for research. For the current study, the linking of administrative data provided a rich source of complementary information on: diagnosis of melanoma (CCR); costs associated with skin cancer (MBS, PBS and the APDC); and skin cancer mortality (CCR, APDC). Second, maximising the utility of the linked data set required a flexible data analysis that was logical and robust. The linkage process followed a sequential strategy that aimed to minimise the number of false positive records. The diagnosis criteria for melanoma and NMSC were informed using relevant international classification of disease coding. The statistical approach enabled a comprehensive and rigorous assessment of the lifetime costs of skin cancer in NSW. The costing approach was broadly consistent with other studies analysing Medicare-linked population-based databases in the United States [15-18, 52]. Third, consistent with other costing studies, our analysis has attempted 
to place a monetary value on indirect costs $[27-29,53]$. Our analysis only considers the economic value of productive years of life lost is a conservative estimate of mortality. Other studies quantify the economic value of all years of life lost, not just that before the age of 65 years [28].

\section{Comparability with other studies}

In spite of methodological differences, the estimated cost of skin cancer in NSW is generally consistent with previous Australian and International studies (Table 5) [29-31, 54, 55]. Compared with our estimate of the average cost per incident case of melanoma (AUD\$44,796), the English study calculated AUD\$67,567 [31], the Swedish study AUD\$66,738 [29], and the New Zealand study AUD\$30,326 [30]. Compared with our estimate of the average cost per incident case of NMSC (AUD\$2459), the English study calculated AUD\$5955 [31], the Swedish study AUD\$1775 [29], and the New Zealand study AUD\$802 [30].

Previous estimates for the cost of skin cancer in Australia only valued direct costs. Compared with our estimate of the average direct cost per incident case of melanoma (AUD\$10,230), other Australian estimates ranged from AUD $\$ 14,805$ in a 1993-94 study [55] to AUD\$4561 in a 2000-01 study [54]. Compared with our estimate of the average direct cost per incident case NMSC (AUD\$2336), other Australian estimates ranged from AUD\$1496 for the 1993-94 study [55] and AUD\$979 for the 2000-01 study [54].

\section{Conclusion}

This study provides new evidence on the economic costs associated with skin cancer in NSW, Australia. Although this analysis is based on the latest epidemiological and economic evidence, there are still large knowledge gaps in understanding the wider impact of skin cancer on society. This lack of data means that the study most likely under-estimates the true cost of skin cancer in NSW.

A key factor underpinning the strategic plan of the Cancer Institute NSW is the knowledge that both melanoma and NMSC are highly preventable. The most effective means of reducing risk of developing skin cancer is to avoid direct exposure to UVR during the time of day when solar UVR levels are moderate to extreme. As a consequence of this analysis, we are in a better position to quantify the savings to society of reducing the incidence of skin cancer through preventive strategies such as sunscreen or mass media campaigns efforts. These savings are likely to be significant given the average lifetime cost of skin cancer in NSW is AUD\$44,796 per melanoma case and AUD $\$ 2459$ per NMSC case.

\section{Abbreviations}

APDC: Admitted patient data collection; AUD: Australian dollar; BCC: Basal cell carcinoma; CCR: Central Cancer Registry; DW: Disability weights; GEE: General estimating equations; ICD-10-AM: International Statistical Classification of Diseases, 10th revision; MBS: Medical Benefits Scheme; NZ: New Zealand; NMSC: Non-melanoma skin cancer; NSW: New South Wales; PBS: Pharmaceutical Benefits Scheme; PYLL: Potential years of life lost; SCC: Squamous cell carcinoma; UK: United Kingdom; UVR: Ultra violet radiation.

\section{Competing interests}

Cancer Institute NSW provided funding to access linked data and conduct the study.

\section{Authors' contributions}

CD was responsible for all facets of this study and preparing the manuscript. $\mathrm{RL}$ contributed to the analysis and manuscript preparation. JB contributed to methods, analysis, interpretation and manuscript preparation. MC contributed to all facets of this research including writing ethic application, assisting in data access and manuscript preparation. AW contributed to methods, analysis and manuscript preparation. DP contributed to all facets of this research including methods, data access, analysis, interpretation and manuscript preparation. AS contributed to conceptual design, interpretation and manuscript preparation. All authors read and approved the final manuscript.

\section{Acknowledgments}

The research team would like to acknowledge the support and funding received from Cancer Institute NSW to access linked data and conduct the study. We would like to thank the Centre for Health Record Linkage for performing data linkage and NSW Ministry of Health, the Sax Institute and the Cancer Institute for providing access to their datasets. We would also like to thank State Cover Mutual Ltd and the Skin Cancer Audit and Research Database (SCARD) for access to their datasets. Prof Bruce Armstrong, Dr Anne Cust, Dr Tim Dobbins from the University of Sydney and Nicola Creighton from the Cancer Institute provided valuable assistance and insight throughout the project. Thanks also to Prof Rachel Morton, Caroline Watts and Alecia Brookes. Dr Stephen Begg from La Trobe University and Professor Theo Vos from the University of Washington provided advice on the epidemiological data. Kim Edmunds from HMRI provided editorial assistance. The team at SURE provided clarification and access to linked data. Any omissions or errors in analysis or interpretation of data rest solely with authors.

\section{Author details}

${ }^{1}$ Hunter Medical Research Institute, University of Newcastle, Locked Bag 1000, New Lambton, NSW 2305, Australia. ${ }^{2}$ Centre for Applied Health Economics, Griffith University, Logan Campus L03 2.15, Meadowbrook 4131, Australia. ${ }^{3}$ Cancer Institute NSW, PO Box 41, Alexandria, NSW 1435, Australia. ${ }^{4}$ School of Public Health, University of Sydney, Level 6, The Hub, Charles Perkins Centre (D17), Sydney, NSW 2006, Australia. ${ }^{5}$ National Drug and Alcohol Research Centre, University of New South Wales Sydney, Sydney, NSW 2052, Australia.

Received: 23 May 2015 Accepted: 14 September 2015

Published online: 23 September 2015

\section{References}

1. American Cancer Society. Cancer Facts \& Figures 2013. http://www.cancer. org/acs/groups/content/@epidemiologysurveilance/documents/document/ acspc-036845.pdf. Accessed January 31, 2013.

2. Australian Institute of Health and Welfare. Cancer in Australia: an overview, 2012. Cancer series no. 74. Cat. No. CAN 70. Canberra: AlHW; 2012

3. Ferlay J, Shin HR, Bray F, Forman D, Mathers C, Parkin DM. GLOBOCAN 2008 v1.2: Cancer Incidence and Mortality Worldwide: IARC Cancer base No.10. Lyon, France: International Agency for Research on Cancer; 2010.

4. Rogers HW, Weinstock MA, Harris AR, Hinckley MR, Feldman SR, Fleischer $A B$, et al. Incidence estimate of nonmelanoma skin cancer in the United States, 2006. Arch Dermatol. 2010;146(3):283-7.

5. Staples MP, Elwood M, Burton RC, William JL, Marks R, Giles GG. Non-melanoma skin cancer in Australia: the 2002 national survey and trends since 1985. MJA. 2006;184:6-10. 
6. Australian Bureau of Statistics. Causes of death Cat. No. 3303.0. Canberra: ABS; 2013.

7. International Agency for Research on Cancer. World Cancer Report 2014 Geneva: WHO; 2014.

8. Cancer Council Australia. Australian Cancer Network Melanoma Guidelines Revision Working Party, Clinical Practice Guidelines for the Management of Melanoma in Australia and New Zealand. Wellington Cancer Council Australia and Australian Cancer Network, Sydney and New Zealand Guidelines Group; 2008.

9. National Cancer Control Initiative. The 2002 National Non-Melanoma Skin Cancer Survey. A report by the NCCI Non-melanoma skin cancer working groups. Melbourne: NCCl; 2003.

10. Cancer Council Australia. Basal cell carcinoma, squamous cell carcinoma (and related lesions) - a guide to clinical management in Australia. Sydney: Cancer Council Australia and Australian Cancer Network; 2008.

11. Stern RS. Prevalence of a history of skin cancer in 2007: results of an incidence-based model. Arch Dermatol. 2010;146(3):279-82.

12. Australian Institute of Health and Welfare. Cancer incidence projections: Australia, 2011 to 2020, vol. Cancer Series no. 66. Cat. No. CAN 62. Canberra: AlHW; 2012

13. Aitken $\mathrm{R}$, Morrell S, Barraclough $\mathrm{H}$, Baker D, Clements $\mathrm{M}$, Jelfs $\mathrm{P}$, et al. Cancer incidence and mortality projections in New South Wales, 2007 to 2011. Sydney: Cancer Institute NSW; 2008

14. Baade P, Coory M. Trends in melanoma mortality in Australia: 1950-2002 and their implications for melanoma control. ANZJPH. 2005;29(4):383-6.

15. Clegg LX, Reichman ME, Miller BA, Hankey BF, Singh GK, Lin YD, et al. Impact of socioeconomic status on cancer incidence and stage at diagnosis: selected findings from the surveillance, epidemiology, and end results: National Longitudinal Mortality Study. Cancer Causes Control. 2009;20(4):417-35

16. Davis KL, Mitra D, Kotapati S, Ibrahim R, Wolchok JD. Direct economic burden of high-risk and metastatic melanoma in the elderly: evidence from the SEER-Medicare linked database. Appl Health Econ Health Policy. 2009;7(1):31-41.

17. Ekwueme DU, Guy GP, Li C, Rim SH, Parelkar P, Chen SC. The health burden and economic costs of cutaneous melanoma mortality by race/ethnicity-United States, 2000 to 2006. J Am Acad Dermatol. 2011;65(5 Suppl 1):S133-43.

18. Seidler AM, Pennie ML, Veledar E, Culler SD, Chen SC. Economic burden of melanoma in the elderly population: population-based analysis of the Surveillance, Epidemiology, and End Results (SEER)-Medicare data. Arch Dermatol. 2010;146(3):249-56

19. Pereira de Souza RJ, Mattedi AP, Correa MP, Rezende ML, Ferreira AC. An estimate of the cost of treating non-melanoma skin cancer in the state of Sao Paulo, Brazil. An Bras Dermatol. 2011:86(4):657-62.

20. Augustin M, Blome C, Rustenbach SJ, Reusch M, Radtke M. Routine skin cancer screening in Germany: First data on the impact on health care in dermatology. J Dtsch Dermatol Ges. 2010;8(9):674-80.

21. Leiter U, Marghoob AA, Lasithiotakis K, Eigentler TK, Meier F, Meisner C, et al. Costs of the detection of metastases and follow-up examinations in cutaneous melanoma. Melanoma Res. 2009:19(1):50-7.

22. Alexandrescu DT. Melanoma costs: a dynamic model comparing estimated overall costs of various clinical stages. Dermatol Online J. 2009;15(11):1.

23. Stang A, Stausberg J, Boedeker W, Kerek-Bodden H, Jockel KH. Nationwide hospitalization costs of skin melanoma and non-melanoma skin cancer in Germany. J Eur Acad Dermatol Venereol. 2008;22(1):65-72.

24. Chevalier J, Bonastre J, Avril M-F. The economic burden of melanoma in France: assessing healthcare use in a hospital setting. Melanoma Res. 2008;18(1):40-6.

25. Chen JG, Fleischer AB, Smith ED, Kancler C, Goldman ND, Williford PM, et al. Cost of nonmelanoma skin cancer treatment in the United States. Dermatol Surg. 2001;27(12):1035-8

26. Guy G, Ekwueme D, Tangka F, Richardson L. Melanoma treatment costs: a systematic review of the literature, 1990-2011. Am J Prev Med. 2012;43(5):537-45

27. Guy G, Ekwueme D. Years of potential life lost and indirect costs of melanoma and non-melanoma skin cancer: a systematic review of the literature. Pharmacoeconomics. 2011;29(10):863-74.

28. Bradley CJ, Yabroff KR, Dahman B, Feuer EJ, Mariotto A, Brown ML. Productivity Costs of Cancer Mortality in the United States: 2000-2020. J Natl Cancer Inst. 2008;100(24):1763-70. doi:10.1093/jnci/djn384.
29. Tinghog G, Carlsson P, Synnerstad I, Rosdahl I. Societal cost of skin cancer in Sweden in 2005. Acta Derm-Venereol. 2008;88(5):467-73.

30. O'Dea D. The costs of skin cancer to New Zealand. Cancer Society of New Zealand: Wellington; 2009.

31. Morris S, Cox B, Bosanquet N. Cost of skin cancer in England. Eur J Health Econ. 2009;10(3):267-73.

32. Eriksson T, Tinghög G. Societal cost of skin cancer in Sweden in 2011. Acta Derm Venereol. 2015:95(3):347-8.

33. Cancer Institute New South Wales. NSW skin cancer prevention strategy 2012-15. Sydney: Cancer Institute NSW; 2012.

34. Drummond M, Torrance G, O Brien B, Stoddart G. Methods for the economic evaluation of health care programmes. New York: Oxford University Press; 2005.

35. Cancer Institute New South Wales. NSW Central Cancer Registry Data Access. Sydney: CINSW; 2013. http://www.cancerinstitute.org.au/data-and-statistics/ cancer-registries/nsw-central-cancer-registry-data-access.

36. Australian Bureau of Statistics. Estimated resident population, by age and sex. Catalogue no. 3201.0. Canberra: ABS; 2013

37. Marks R, Staples MP, Giles GG. Trends in non-melanocytic skin cancer treated in Australia: the second national survey. Int J Cancer. 1993;53:585-90.

38. Australian Institute of Health and Welfare. Non-melanoma skin cancer, General practice consultations, hospitalisation and mortality. Cat. No. 39. Canberra: AlHW; 2008.

39. Sax Instittute. 45 and Up Study. Sydney: Sax Instittute; 2013. https://www saxinstitute.org.au/our-work/45-up-study/. Accessed June 2012.

40. Australian Bureau of Statistics. NSW Health Department, admitted patient data collection. Cat. No. 1368.1. Canberra: ABS; 2013.

41. Australian Government Department of Human Services. Pharmaceutical Benefits Scheme (PBS). Canberra: Australian Government; 2013. http:// www.pbs.gov.au/pbs/home. Accessed June 2012.

42. Australian Government Department of Human Services. Medicare Benefits Schedule. Canberra: Australian Government; 2013. http://www.mbsonline. gov.au/. Accessed June 2012.

43. Government of New South Wales. Registry of Births, Deaths and Marriages (RBDM). Sydney: NSW Government; 2013. http://www.bdm.nsw.gov.au/. Accessed June 2012

44. World Health Organisation. International Statistical Classification of Diseases and Related Health Problems 10th Revision. Geneva: WHO; 2013. http:// apps.who.int/classifications/icd10/browse/2010/en. Accessed June 2012.

45. Australian Institute of Health and Welfare. Health expenditure Australia 2010-11. Health and welfare expenditure series no. 47. Cat. No. HWE 56 Canberra: AlHW; 2012.

46. Begg S, Vos T, Barker B, Stevenson C, Stanley L, Lopez AD. The burden of disease and injury in Australia 2003. PHE 82. Canberra: AlHW; 2007.

47. Single E, Collns D, Easton B, Harwood HJ, Lapsley H, Kopp P, et al. International guidelines for estimating the costs of substance abuse. Geneva: World Health Organisation; 2003.

48. Australian Bureau of Statistics. Average weekly earnings. Cat. No. 6302.0. Canberra: ABS; 2013.

49. Australian Bureau of Statistics. Labour force. Cat. No. 6202.0. Canberra: ABS; 2013.

50. Safe Work Australia. National hazard exposure worker surveillance: exposure to direct sunlight and the provision of sun exposure controls in Australian workplaces. Canberra: Commonwealth of Australia; 2010.

51. Economics A. The economic value of informal care in 2010: Report for Carers Australia. Access Economics: Canberra; 2010

52. Barzilai DA, Koroukian SM, Neuhauser D, Cooper KD, Rimm AA, Cooper GS The sensitivity of Medicare data for identifying incident cases of invasive melanoma (United States). Cancer Causes Control. 2004;15(2):179-84.

53. Styperek A, Kimball AB. Malignant melanoma: The implications of cost for stakeholder innovation. Am J Pharm Ben. 2012;4(2):66-76.

54. Australian Institute of Health and Welfare. Health system expenditures on cancer and other neoplasms in Australia, 2000-2001, in Health and Welfare Expenditure Series no. 22. Canberra: AlHW; 2005.

55. Mathers C, Penm R, Sanson-Fisher R, Carter R, Campbell E. Health system costs of cancer in Australia 1993-94. AlHW Cat. No. HWE 4. Canberra: AlHW and National Cancer Countrol Intitiative; 1998. 